\title{
The Short: Limited Prospects
}

\author{
By Patricia Thompson \\ Spring 1995 Issue of KINEMA \\ Johnston ... Johnston. \\ Producer, Writer, Director: John Hopkins. \\ Cast: Henry Czerny, Lenore Zann. \\ Canada 1994, 23 min.
}

The wind soughs behind the opening credits, the camera slowly angles and drifts over the glittering downtown skyscrapers, music invades the senses. Johnston (Henry Czerny) stands unmoving at a high window gazing outward. A woman's voice calls the film's title, Johnston . . . Johnston. Queen Bee (Lenore Zann) stands in the doorway chiding Johnston on his attitude: "You're not setting a good example here" and pointing out that he needs "focus." Surrounded by toadies and yes-men and women, she reinforces her philosophy by demonstrating an analogy between work and golf, and purrs away on her electric golf cart.

Johnston goes back to brooding in his office. Behind him stretches the general office filled with long lines of brokers glued to telephones and computers. Johnston has to escape -- he makes a mad rush for street level, but it seems unreal and the people bizarre. He jumps on a bus (and sits next to the director reading Beckett's End Game) but soon flings himself off. He realises he is being filmed, he finds he has a gun, he advances and falls to the pavement. An ambulance arrives, two stretcher attendants bear him away, the siren wails. The camera starts its angled circle of the office skyscrapers ... ending on Johnston standing motionless at his window, his face in close-up overlaid with the image of rows of floors and windows criss-crossing his face like bars.

This surreal and ingenious film weaves an elliptical tale of the burnout of a corporate minion in the nineties. The lead figure doesn't utter a word throughout, but his inner agonies are projected on-screen with style, acerbic wit and a dash of morbid humour. The acting is first-rate, Gerald Packer's camerawork soars, the script is an interesting puzzle, and there's an engagingly original music score by Daniel Scott. In fact, the whole is a really superb calling card for director/ writer/ producer John Hopkins. He can be proud to show his film to anyone in the business -- be it a festival, major studio or TV. Unfortunately this little gem will probably never reach commercial cinemas anywhere.

The film is 23-minutes long, shot in $35 \mathrm{~mm}$, with Dolby Stereo SurroundSound, starring Henry Czerny of The Boys of St. Vincent fame (a much-debated film produced in 1993 by the Canadian Broadcasting Corporation, about sexual abuse of children in an orphanage run by Catholic brothers in Newfoundland). Czerny went on to a substantial role alongside Harrison Ford in Clear and Present Danger. The co-star Lenore Zann, well-known from TV roles (Atom Egoyan's Gross Misconduct, Love and Hate and the CBC series Street Legal) is also a co-producer. The supporting cast is peppered with top-notch Canadian actors in cameo roles.

Johnston...Johnston was presented at the 1994 Montréal World Film Festival but rejected in that year by several other Canadian film competitions: The Toronto International Film Festival (the director nevertheless organized his own luncheon screening for 50 invited guests there) and the Vancouver International Film Festival. It has also been shut-out by the 1995 Local Heroes International Film Festival organized by the National Screen Institute of Canada in Edmonton.

Short film directors face considerable difficulties with the film business establishment anywhere. Let's not whinge on about a duty to support films only in their country of origin; let's advocate showing a film for its skill, inventiveness, flair, talent, craft... As for Hopkins, he is going to make it anyway.

\section{Author Information}

Patricia THOMPSON (d. 1999) was Publisher and Editor of Film Canada Yearbook and Canadian Editor for the International Motion Picture Almanac and the International Television and Video Almanac (Quigley, 
NY). She was reviewing Canadian short films for several decades. 